\title{
Anti-amnestic effect of Spirulina platensis in high-fat diet-induced obese mice
}

\author{
Seon Kyeong Park, Hye Ju Han, Jong Min Kim, Jin Yong Kang, Su Bin Park, \\ Seol Ki Yoo, Jae Hong Jeong, Jong Hee Kwon, Ho Jin Heo* \\ Division of Applied Life Science (BK21 plus), Institute of Agriculture and Life Science, \\ Gyeongsang National University, Jinju 52828, Korea
}

\section{고지방 식이 동물모델에서 스피룰리나(Spirulina platensis)의 기억능력 장애 개선효과}

\author{
박선경 · 한혜주·김종민 · 강진용·박수빈 · 유슬기 · 정재홍·권종희 · 허호진* \\ 경상대학교 응용생명과학부(BK21PIus), 농업생명과학연구원
}

\begin{abstract}
The aim of this study was to examine the ameliorating effect of Spirulina platensis (SP) on cognitive dysfunction in high-fat-diet (HFD) mice. Glucose tolerance was evaluated using the intraperitoneal glucose tolerance test (IPGTT). The results showed that the area under the curve (AUC) decreased $20 \%$ in the SP group compared to that in the HFD group. The ameliorating effect on HFD-induced learning and memory impairment was investigated using Y-maze and Morris water maze tests. The administration of SP effectively restored learning and memory function compared to that in the HFD group. Using blood senum analysis, liver and kidney function and lipid metabolism-related biomarkers were measured. Generally, administration of SP effectively restored lipid-metabolism by increasing HDLC (HTR) and decreasing LDLC. The antioxidant effects in tissues were also investigated by measuring the superoxide dismutase (SOD) content, oxidized glutathione (GSH)/total GSH ratio, and malondialdehyde (MDA) content, and the administration of SP effectively improved the antioxidant system in the brain and liver tissues. The improvement of cognitive function was confirmed by the inhibitory effect of acetylcholinesterase (AChE) as a biomarker of the cholinergic system, which plays an important role in neurotransmission, and the SP group showed significant inhibition of AChE. Based on these results, SP could be used to improve brain function by ameliorating the HFD condition.
\end{abstract}

Key words : Spirulina platensis, high-fat diet, acetylcholinesterase, learning and memory function

\section{서 론}

영양소의 과다섭취 및 잘못된 식습관은 체내 에너지 대 사 장애를 유발함으로써 비만, 당뇨, 고혈압, 심혈관 질환 등과 같은 다양한 만성대사질환을 발생시킨다(1-3). 비만에

*Corresponding author. E-mail : hjher@gnu.ac.kr Phone : 82-55-772-1907, Fax : 82-55-772-1909

Received 5 June 2018; Revised 27 July 2018; Accepted 30 July 2018.

Copyright (c) The Korean Society of Food Preservation. All rights reserved.
의하여 포도당 대사에 중요한 조직인 근육과 간에 지방이 축적되면, 이를 분해하는 대사과정이 촉진되어 유리지방산 (acyl-CoA)을 혈중으로 분비한다. 분비된 유리지방산은 diacylglycerol(DAG), ceramide와 같은 지질 대사체로 인체 내 에너지원으로 사용되는 포도당의 이용률을 감소시키고, 인슐린 신호전달 경로를 저해함으로써 인슐린 저항성을 발생시키게 된다(4). 뇌는 포도당을 주요 에너지원으로 소 모하는 기관으로 대뇌 피질, 핵, 번연계 및 해마와 같은 부위에 주로 인슐린 수용체들이 분포되어 있으며, 뇌에서 발생되는 인슐린 저항성은 학습능력 및 기억력과 같은 인지 기능을 담당하는 뇌기능 장애를 유발하게 된다(5). 뿐만 
아니라, 비만은 여러 합병증을 야기하는 주요 위험 요소로, 특히 해마의 시냅스 가소성, 학습 및 기억력과 같은 인지 기능에 손상을 발생시킴으로써 신경 퇴행성 질환을 유발한 다(6). 해마는 학습과 기억 기능에 관여하는 기관으로 brain derived neurotophic factor(BDNF)와 같은 세포 성장 인자를 통해 신경 세포를 생성하는 반면, 다양한 외부 요인으로부 터 발생되는 산화적 스트레스는 단백질 및 지질 과산화를 유도하여 이러한 neurogenesis 활성을 저해함으로써 뇌세포 의 기능 저하를 유도하는 것으로 보고되고 있다(7).

또한, 지속적인 인슐린 저항성의 발생은 혈중의 포도당 을 정상적으로 이용하지 못함으로써 고혈당 상태를 지속하게 하며, 포도당의 자가산화, 최종당화산물(advanced glycation end-product, AGEs) 생성 및 폴리올 경로(polyol pathway)의 활성과 같은 다양한 기작이 활성산소종(reactive oxygen species, ROS)의 생성을 촉진시킨다(8). 상대적으로 불포화 지방산의 함량이 높은 뇌 조직은 산화적 스트레스에 매우 취약한 구조를 나타내는데, 이러한 구조적 특징은 뇌신경 세포의 기능장애 및 사멸을 유도함으로써 알츠하이머 (Alzheimer's disease), 파킨슨(Parkinson disease) 및 뇌졸중 등과 같은 퇴행성 뇌신경질환을 유발시키는 것으로 보고되 고 있다(9). 이러한 산화적 스트레스로부터 인체를 보호하 기 위하여, superoxide dismutase(SOD), glutathione reductase (GSH-Px) 및 catalase(CAT)와 같은 체내 내인성 항산화인자 들이 산화-산화방지 균형을 유지한다 $(10,11)$. 하지만 과도 한 산화적 스트레스의 발생은 이러한 체내 항산화체계의 붕괴를 유발하여 인체 내 장기들의 산화적 손상을 발생시키 기 때문에, 당뇨 환자에게 있어 식단 조절과 더불어 항산화 제 섭취에 대한 필요성이 대두되고 있다(12).

남조류 중 하나인 스피룰리나(Spirulina platensis; $S$. platensis)는 열대 지역의 알칼리성이 높고 염분이 많은 호수 의 표면에서 주로 자생하며, 광합성 능력이 뛰어나고 영양 소 조성이 우수하여 미래식량으로 주목받고 있다. 스피룰 리나는 단백질이 60-70\% 함유되어 있는 고단백 자원이며, 지방은 6-9\%로 상대적으로 적은 것으로 보고되고 있다. 특히 단백질 속에는 8가지 필수 아미노산이 포함되어 있으 며, 지방의 대부분은 linoleic acid, y-linolenic acid 등의 불포 화 지방산이 차지하고 있다(13). 그 외에도 $\mathrm{B}_{12}$ 및 carotene과 같은 비타민, carotinoid, xanthophyll, phycocyanin과 같은 페놀성 생리활성 성분이 풍부한 것으로 보고되고 있다(14). 최근에는 이러한 스피룰리나를 이용하여 다양한 기능성에 대한 연구가 진행되고 있으며, 신장 장애 회복효과(15), 혈 중 콜레스테롤 저하(16), 항암(17), 항바이러스 활성 효과 (18) 및 Lactobacillus bulgaricus, Streptococcus thermophilus 와 같은 유산균 증식(19)에도 효과를 나타내는 것으로 보고 되고 있다. 다양한 분야에서의 스피룰리나의 기능성에 대 한 연구에도 불구하고, 학습능력 및 기억력과 같은 뇌기능 개선효과 관련 연구는 미흡한 실정이다. 따라서 본 연구는
고지방 식이로 유도된 인지장애 동물모델에서 스피룰리나 의 내당능 개선 효과 및 이로 인한 인지 기능 개선 효과를 확인하고자 하였다.

\section{재료 및 방법}

\section{재료 및 시약}

본 실험에 사용된 스피룰리나(학명: S. platensis)는 한국 해양미세조류은행(KMCC)에서 분양받았다. 배양 온도는 $25^{\circ} \mathrm{C}$, 조도는 $100 \mu \mathrm{mol}$ photons $\mathrm{m}^{-2} \mathrm{~s}^{-1}(\mathrm{LI}-189 \mathrm{Li}-\mathrm{Cor}$, PAR quantum sensor, Lincoln, NE, USA)를 유지하였으며, 영양 배지는 중화살균방법을 적용한 Zarrouk 배지를 이용하였다 (20). 마우스 실험동물에 대한 스피룰리나 식이실험을 위해 서 autoflotation 조건하에 농축된 스피룰리나 셀을 사용하 였다. 사용된 시약은 phenylmethylsulfonyl fluoride, metaphosphoric acid, thiobarbituric acid, phosphoric acid, 5,5'-dithiobis-(2-nitrobenzoic acid), sodium phosphate, Triton $\mathrm{X}-100$, superoxide dismutase assay kit는 Sigma-Aldrich Chemical Co.(St. Louis, MO, USA)에서 구입하였으며, glutathione assay kit는 Enzo Diagnostics(Farmingdale, NY, USA)에서 구입하여 사용했다. 그 이외에 사용된 용매 및 시약은 모두 일급 이상의 등급을 사용하였다.

\section{실험동물 사육 및 실험군 구성}

본 실험에 사용된 동물은 $\mathrm{C} 57 \mathrm{BL} / 6 \mathrm{~N}$ 마우스로 4주령의 수컷을 (주샘타코 바이오(Osan, Korea)에서 구입하였다. 일 주일의 적응 기간을 거친 뒤 실험동물은 정상 대조군 (normal control, NC)과 고지방 식이군(high-fat diet, HFD), 일반식이 전환군(conversion of HFD to normal diet, $\mathrm{CND}$ ), 스피룰리나 식이군 $(S$ platensis, SP)으로 나누어 12주 동안 사육하였다. 일반식이 전환군(CND)은 일종의 양성대조군 으로 디자인되었다. 1-8주 차는 정상 대조군을 제외한 다른 군들은 고지방 식이를 공급하였으며, 9주 차부터 일반식이 전환군은 일반식이로 전환시켰고, 스피룰리나 투여군은 건 조 질량으로 $200 \mathrm{mg}$ 에 해당하는 스피룰리나 농축액을 4주 동안 매일 경구 투여하였다. 실험동물을 사육하는 기간 동 안 온도 $22 \pm 2{ }^{\circ} \mathrm{C}$, 상대습도 $50 \pm 5 \%$ 를 유지하며 충분한 식수 와 사료를 지급하였고, 조명 시간을 12 시간 간격으로 조절 해 동일한 사육 환경을 제공했다. 실험동물의 체중 측정은 시험개시일(0 week), 8주간의 고지방 식이 급여 후(8 weeks) 및 4주간의 샘플 식이 후(12 weeks) 총 3회 측정하였다. 모든 실험은 경상대학교 동물실험 윤리위원회 승인 (IACUC 승인번호: GNU-161116-M0065)하에 수행하였다.

복강 내 당부하 검사(intraperitoneal glucose tolerance test, IPGTT)

12 시간 절식시킨 실험동물의 혈당을 측정한 뒤, $2 \mathrm{~g} / \mathrm{kg}$ 
of body weight 농도의 포도당을 복강 주사하였다. 복강 주사 후, 일정 시간 $(15,30,60$, 및 120 분)마다 당 측정 검사기 (Accu-chek, Roche Diagnostic, Basel, Switzerland)를 이용하 여 꼬리정맥의 혈당을 측정하였다.

\section{Y-maze test}

Y-maze는 흰색 플라스틱 재질의 $\operatorname{arm}$ (길이 $33 \mathrm{~cm}$, 높이 $15 \mathrm{~cm}$, 넓이 $10 \mathrm{~cm}$ 인) 3 개를 $\mathrm{Y}$ 자 형태로 구성한 것을 사용하 였으며, 각 $\mathrm{arm}$ 을 $\mathrm{A}, \mathrm{B}, \mathrm{C}$ 로 정하였다. 3 개 중 한 구역을 지정하여 실험동물을 놓고 8 분 동안 실험동물의 이동경로 를 smart 3.0 video tracking system(Panlab, Barcelona, Spain) 을 이용하여 분석하였다. 3 개의 서로 다른 arm을 연속으로 이동했을 경우 1점(actual alternation)을 부여하고, 총 arm의 통과횟수(number of arm entries)와 함께 다음의 식을 이용 하여 계산하였다.

$$
\text { Alternationbehavior }(\%)=\frac{\text { actul alternation }}{\text { nmber of armentries }-2} \times 100
$$

\section{Morris water maze test}

실험동물의 공간 학습 및 기억력을 측정하기 위해 Morris 방법(21)을 변형하여 실시하였다. 원형 수조(지름 $150 \mathrm{~cm}$, 높이 $60 \mathrm{~cm}$ ) 안에 물을 채워 탈지분유를 녹이고, 수조 사분 면(N, S, E, W)의 한 구역(W zone)에 흰색의 도피대(escape platform)를 설치하였다. 실험 첫 날(visible test)은 수위를 낮게 조절하여 도피대를 육안으로 확인할 수 있도록 하였 고, 실험동물에게 도피대의 위치를 학습시켰다. 이후 4 일 동안 사분면을 통해 매번 입수 시작점을 다르게 하여 하루 1 번씩 반복 훈련을 실시하였다(hidden test). 실험동물이 60 초안에 도피대를 찾을 경우 10 초간 도피대 위에 머물게 하였으며, 찾아내지 못했을 경우에는 도피대 위로 유인시 켜 20초간 위치를 인지시키도록 하였다. Hidden test 후, 도피대를 제거하고 90 초 동안 도피대가 위치해 있던 $\mathrm{W}$ zone에 머무르는 시간을 기록하였다(probe test). 모든 데이 터는 수조 위에 설치된 smart 3.0 video tracking system(Panlab)으로 기록하여 분석하였다.

\section{혈청 내 바이오마커 분석}

행동 시험 종료 후, 혈청 내 바이오 바이오마커 분석을 위하여 실험동물의 복대정맥에서 채혈한 혈액은 원심분리 $\left(10,000 \times g, 10\right.$ 분, $\left.4{ }^{\circ} \mathrm{C}\right)$ 하여 혈청을 분리하였다. 혈청 내 glutamic oxaloacetic transaminase(GOT), glutamic pyruvic transaminase(GPT), blood urea nitrogen(BUN), creatine (CRE), lactate dehydrogenase(LDH), triglyceride(TG), total cholesterol(TCHO) 및 high density lipoprotein cholesterol (HDLC)은 혈청분석기(Fuji dri-chem 4000i, Fuji film Co., Tokyo, Japan)를 이용하여 분석하였다. LDLC는 TCHO-
(HDLC+TG/5)로 계산하였으며, $\mathrm{HDLC}$ 함량은 $\mathrm{TCHO}$ 에 대 한 비율 $(\mathrm{HTR}(\%)=(\mathrm{HDLC} / \mathrm{TCHO}) \times 100)$ 로 계산하여 나타냈 다(22).

마우스 뇌, 간 조직 중의 Superoxide dismutase(SOD) 활성 측정

Phosphate buffered saline(PBS)으로 조직을 균질화한 균 질액을 원심분리 $\left(400 \times g, 5\right.$ 분, $\left.4^{\circ} \mathrm{C}\right)$ 한 후 상층액을 제거하고 펠렛을 취하였다. 펠렛에 $1 \times$ cell extraction buffer[10×SOD buffer $0.5 \mathrm{~mL}, 20 \%$ triton X-100 $0.1 \mathrm{~mL}$, distilled water 4.4 $\mathrm{mL}$, phenylmethanesulfonyl fluoride in ethanol $5 \mu \mathrm{L}$ 를 넣고, ice에서 30 분 동안 추출하였다. 추출물은 원심분리 $(10,000$ $\times g, 10$ 분, $4^{\circ} \mathrm{C}$ )되어 상층액의 SOD 함량을 SOD assay kit(Sigma-Aldrich Chemical Co.)를 사용하여 측정하였다.

마우스 뇌, 간 조직 중의 glutathione(GSH) 함량 측정

Metaphosphoric acid(5\%)를 넣어 균질화한 조직은 원심 분리 $\left(14,000 \times g, 15\right.$ 분, $\left.4^{\circ} \mathrm{C}\right)$ 후, 상층액을 total GSH 함량 측정에 사용하였다. Oxidized GSH 함량은 $2 \mathrm{M}$ 4-vinylpyridine $10 \mu \mathrm{L}$ 를 상온에서 1 시간 방치 후, 실험에 사용하였다. 전처리된 total GSH와 oxidized GSH 함량은 GSH(GSSG/GSH) assay kit(Enzo Diagnostics)를 이용하여 측정하였다.

\section{마우스 뇌, 간 조직 중의 지질 과산화물 함량 측정}

조직 내 지질과산화 정도를 측정하기 위하여, 지질과산 화물 중 하나인 malondialdehyde(MDA) 함량을 측정하였 다. 조직무게에 10 배의 $\mathrm{PBS}$ 를 넣고 균질화한 균질액을 원 심분리 $\left(2,450 \times g, 10\right.$ 분, $\left.4^{\circ} \mathrm{C}\right)$ 하여 상층액을 얻었다. 상층액 $160 \mu \mathrm{L}$ 에 1\% phosphoric acid $960 \mu \mathrm{L}, 0.67 \%$ thiobarbituric acid $320 \mu \mathrm{L}$ 를 넣고 혼합한 다음 1 시간 동안 $95^{\circ} \mathrm{C}$ 의 끓는 물에서 반응시켰다. 반응 종료 후 $532 \mathrm{~nm}$ 에서 상층액의 흡광도(Libra S32PC, Biochrom Ltd., Cambridge, UK)를 측 정하였다.

\section{마우스 뇌 조직 중의 acetylcholinesterase(AChE) 활성 측정}

PBS로 조직을 균질화한 균질액을 원심분리 $(14,000 \times g$, 30 분, $4^{\circ} \mathrm{C}$ )한 후 상층액을 사용하였다. 상층액 $5 \mu \mathrm{L}$ 에 50 $\mathrm{mM}$ sodium phosphate buffer $65 \mu \mathrm{L}$ 를 혼합하여 $37^{\circ} \mathrm{C}$ 에서 15 분간 반응시켰다. 반응 후, $500 \mu \mathrm{M}$ substrate solution 70 $\mu \mathrm{L}$ 를 혼합하여 10 분간 반응시켰고, microplate reader (Bio-rad, Hercules, CA, USA)를 이용하여 $405 \mathrm{~nm}$ 에서 흡광 도를 측정하였다. 조직 중의 $\mathrm{AChE}$ 활성은 대조군 대비 \% 활성으로 표현하였다(23).

\section{통계처리}

각 실험의 결과는 mean $\pm \mathrm{SD}$ 로 표기하였고, 평균에 대한 
검증은 SAS version 9.1 software(SAS institute, Cary, NC, USA)를 이용하여 분산분석(analysis of variance, ANOVA) 과 Duncan's multiple range test로 유의적인 차이를 검증하 여 나타냈다 $(\mathrm{p}<0.05)$.

\section{결과 및 고찰}

\section{체중변화}

8 주간의 고지방 식이를 급여하였고, 8 주간의 유도기간 및 스피룰리나 섭취에 따른 실험동물의 체중변화를 측정한 결과는 Table 1과 같다. 시험개시 체중은 평균 $20.36 \mathrm{~g}$ 으로 각 실험군간 차이를 나타내지 않았다. 8 주간 고지방 식이를 급여하여 비만을 유도한 결과, 정상 대조군 $(\mathrm{NC} ; 25.14 \mathrm{~g})$ 대비 고지방 식이 섭취 군(고지방 식이군(HFD); $34.86 \mathrm{~g}$, 일반식이 전환군(CND); $35.14 \mathrm{~g}$, 스피룰리나 투여군(SP); $34.43 \mathrm{~g}$ )들은 평균 $34.81 \mathrm{~g}$ 으로 약 $138.46 \%$ 증가된 체중증가 를 나타냈다. 반면, 4 주간의 스피룰리나 섭취 $(\mathrm{SP} ; 37.29 \mathrm{~g})$ 는 고지방 식이군(HFD; $40.71 \mathrm{~g}$ ) 대비 약 $8.42 \%$ 유의적인 체중 감소를 나타냈으며, 이러한 결과는 스피룰리나의 섭취가 고지방 식이로 인한 체중 증가에 대하여 억제효과를 나타낼 수 있는 것으로 사료된다.

복강 내 당부하 검사(intraperitoneal glucose tolerance test, IPGTT)

Type 2형 당뇨병의 전기 또는 초기에 발생되는 인슐린 저항성은 심각한 뇌기능의 기능 저하를 유발할 수 있으며, 내당능 장애가 대표적인 특징으로 알려져 있다(24). 인슐린 은 세포 표면에 glucose transporter type 4(GLUT4)를 전좌시 켜 세포 내로 포도당이 유입되는 것을 도와 혈중 포도당 농도를 감소시키지만, 비만에 의한 인슐린 저항성 상태는 혈중 포도당을 정상적으로 이용하지 못함으로써 내당능 장애를 야기한다(25). 당부하 검사는 내당능 장애 및 간접적 인 인슐린 민감성을 확인하기 위한 대표적인 방법으로 사용 된다(26). 따라서 고지방 식이로 유도된 인지장애 마우스 모델의 내당능 장애 유발 및 스피룰리나의 내당능 장애에
대한 개선효과를 확인하고자 하였다. 포도당을 복강주사한 후 시간별 혈당 측정 결과 및 혈당치 곡선하면적도(area of under curve, AUC)는 Fig. 1과 같다. 시간별 혈당 측정 결과(Fig. $1 \mathrm{~A})$ 에서 $\mathrm{HFD}$ 의 혈당은 15 분 후 급격한 증가를
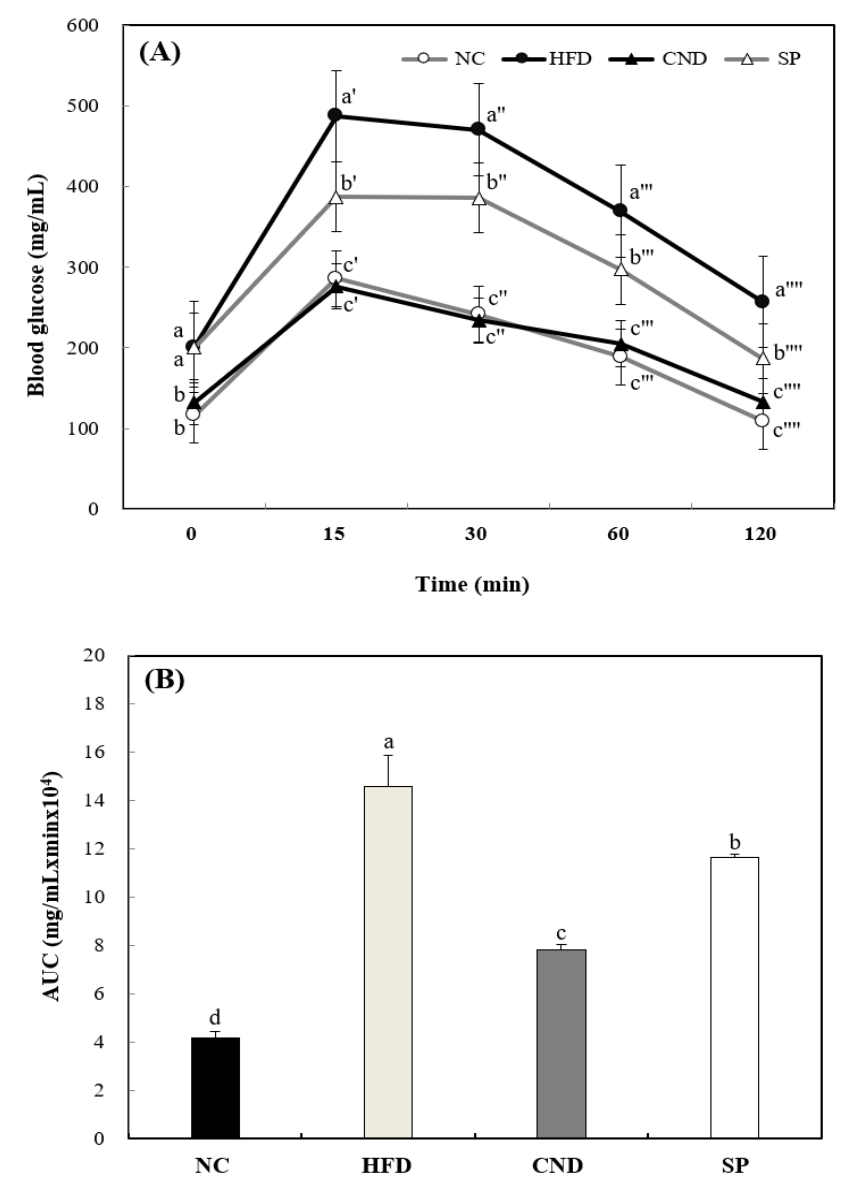

Fig. 1. Effect of Spirulina platensis on intraperitoneal glucose tolerance test (IPGTT) on high-fat diet-induced mice.

Blood glucose concentration during the IPGTT (A) and area under the curve (AUC) value $(\mathrm{B})$.

$\mathrm{NC}$, normal control; HFD, high-fat diet; CND, conversion of HFD to normal diet; $\mathrm{SP}$, Spirulina platensis. Results shown are means $\pm \mathrm{SD}(\mathrm{n}=8)$. Data were statistically considered at $\mathrm{p}<0.05$, and different small letters represent statistical differences.

Table 1. Effect of Spirulina platensis on body weight in high-fat diet mice

\begin{tabular}{cccc}
\hline & \multicolumn{3}{c}{ Body weight $(\mathrm{g})$} \\
\cline { 2 - 4 } Group ${ }^{1)}$ & $\begin{array}{c}\text { Initial } \\
(0 \text { week })\end{array}$ & $\begin{array}{c}\text { Administration starting } \\
(8 \text { weeks })\end{array}$ & $\begin{array}{c}\text { Final } \\
(12 \text { weeks })\end{array}$ \\
\hline NC & $20.00 \pm 0.58^{2) a 3}$ & $25.14 \pm 1.46^{\mathrm{b}}$ & $25.71 \pm 1.98^{\mathrm{d}}$ \\
HFD & $20.71 \pm 0.49^{\mathrm{a}}$ & $34.86 \pm 3.72^{\mathrm{a}}$ & $40.71 \pm 3.15^{\mathrm{a}}$ \\
CND & $20.29 \pm 0.76^{\mathrm{a}}$ & $35.14 \pm 4.45^{\mathrm{a}}$ & $30.00 \pm 2.24^{\mathrm{c}}$ \\
SP & $20.43 \pm 0.79^{\mathrm{a}}$ & $34.43 \pm 2.37^{\mathrm{a}}$ & $37.29 \pm 3.09^{\mathrm{b}}$ \\
\hline
\end{tabular}

\footnotetext{
${ }^{1)} \mathrm{NC}$, normal control; HFD, high-fat diet; CND, conversion of HFD to normal diet; SP, Spirulina platensis.

${ }^{2}$ Results shown are means \pm SD $(n=8)$.

${ }^{3}$ Data were statistically considered at $\mathrm{p}<0.05$, and different small letters represent statistical differences.
} 
나타내었으며, 120 분에서는 $\mathrm{NC}$ 가 원래의 혈당치를 회복한 반면 지속적으로 높은 혈당치를 나타냈다. 또한, AUC 값 (Fig. 1B)에서 $\mathrm{HFD}(14.58)$ 는 NC(4.18) 대비 약 3.49배 상승 된 값을 나타냄에 따라 내당능 장애가 발생된 것으로 판단 된다. 반면, $\mathrm{CND}$ 는 $\mathrm{NC}$ 와 유사한 혈당 감소경향을 나타내 었으며, $\mathrm{AUC}$ 값은 7.83으로 나타났다. $\mathrm{SP}(11.65)$ 는 $\mathrm{CND}$ 보 다는 다소 낮은 효과를 나타내었지만, HFD 대비 $20.08 \%$ 감소된 $\mathrm{AUC}$ 값을 나타냄에 따라 내당능 장애에 대한 개선 효과를 가지는 것으로 판단된다.

최근의 연구에서는 스피룰리나 butanol 분획물이 뛰어난 a-glucosidase 활성 억제 효과 $\left(\mathrm{IC}_{50}=23.0 \pm 0.7 \mu \mathrm{g} / \mathrm{mL}\right)$ 및 전분 부하실험(starch tolerance test)에서의 장내 a-glucosidase에 대한 저해효과 $\left(\mathrm{IC}_{50}=37.5 \pm 2.8 \mathrm{\mu g} / \mathrm{mL}\right)$ 를 나타냈으며 $(27)$, 장 내에서 glucose의 흡수 억제를 통한 혈당강하효과에 대한 가능성을 제시하였다. 이러한 결과는 페놀성 화합물 및 플 라보노이드를 풍부하게 함유하는 스피룰리나 분획물에 의 한 것이라고 보고하였다. 또한, $\mathrm{Ou}$ 등(28)은 alloxan으로 유도된 당뇨 쥐에 스피룰리나로부터 추출된 phycocyanin이 glucokinase를 발현시킴으로써, 공복혈당 장애개선 및 췌장 세포 보호효과를 나타내어 당뇨개선에 도움을 주는 것으로 보고하였다. 뿐만 아니라 MA 등(29)의 연구에서는 streptozotocin(STZ)으로 유도된 1형 당뇨모델에서 스피룰 리나에서 추출된 $\beta$-carotene의 섭취 시 뛰어난 공복 혈당 개선, 물 섭취량 및 식이 섭취량을 개선시키는 것으로 나타 났으며, 이러한 성분은 스피룰리나의 항당뇨 효과를 나타 내는 중요한 물질일 것으로 보고했다. 이러한 결과들을 종 합하여 볼 때, 고지방 식이로 유도된 내당능 장애에 대한 개선효과는 스피룰리나에 함유된 페놀성 화합물, $\beta$ -carotene 및 phycocyanin과 같은 다양한 생리활성 물질들에 의한 것이라고 판단된다.

\section{학습 및 기억력 개선 효과}

고지방 식이로 유도된 내당능 장애 모델에서 스피룰리나 의 기억 및 학습능력 손상에 대한 개선효과를 확인하고자 행동학적 실험을 실시하였다. 미지의 공간을 탐험하려 하 는 쥐의 본능을 바탕으로 공간 학습 및 단기 기억력을 평가 하기 위한 Y-maze 시험결과는 Fig. 2와 같다. HFD는 39.68 회로 $\mathrm{NC}$ (51.97 회) 대비, 각 arm에 들어간 총 횟수(total arm enteries)가 낮게 나타났으며, 고지방 식이로 유도된 비만으로 인하여 운동 능력이 감소되었음을 확인할 수 있었 다. 반면, $\mathrm{CND}(51.44$ 회)와 $\mathrm{SP}(56.81$ 회)에서는 $\mathrm{NC}$ 대비 운동 능력에서 유의적인 차이가 나타나지 않았다. 변경행 동능력(alternation behavior)의 계산 결과(Fig. 2A)에서는 $\mathrm{NC}(27.20 \%)$ 에 비하여 $\mathrm{HFD}$ 는 $21.00 \%$ 로 변경행동능력이 감소되어 단기 기억력 및 공간학습능력의 저하를 관찰할 수 있었다. 반면, $\mathrm{CND}$ 와 $\mathrm{SP}$ 는 각각 $30.40 \%, 25.80 \%$ 로 변경 행동능력이 개선된 것을 확인할 수 있었으며, 모두 $\mathrm{NC}$ 와
유사한 수준으로 공간 학습 및 단기 기억력이 회복된 것으 로 나타났다. Fig. 2B는 동물모델의 움직임에 대한 모식도 로 $\mathrm{NC}$ 에서는 각 $\mathrm{arm}$ 에서의 비슷한 움직임 경향을 나타내 는 반면, $\mathrm{HFD}$ 에서는 한쪽의 arm에 움직임이 치우친 경향을 나타냄을 확인하였고, 스피룰리나 섭취로 인하여 이러한 경향성이 회복됨을 확인하였다.

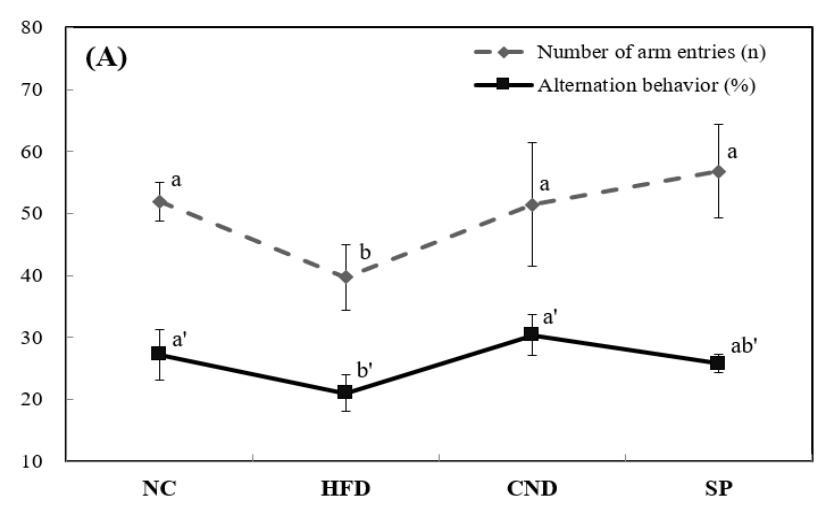

(B)
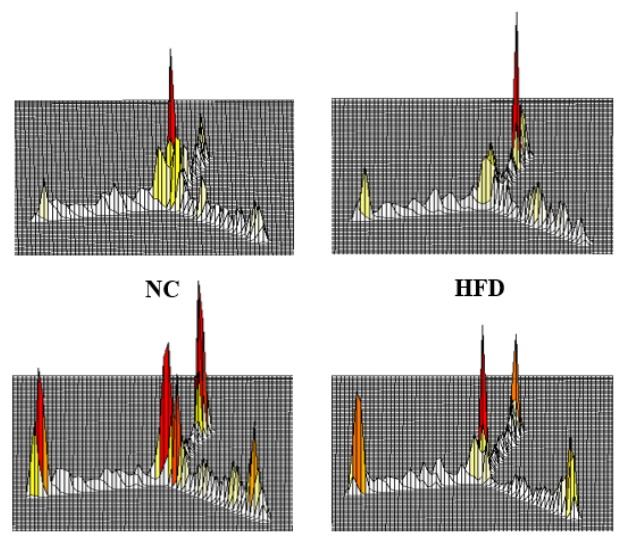

CND

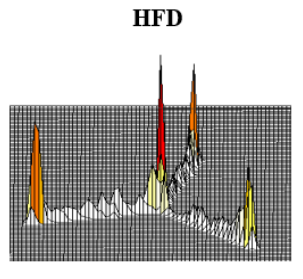

SP

Fig. 2. Effect of Spirulina platensis in high-fat diet-induced learning and memory impairment.

The spontaneous alternation behavior, number of arm entries (A), and path tracing of each groups (B) in the Y-maze test.

$\mathrm{NC}$, normal control; HFD, high-fat diet; CND, conversion of HFD to normal diet; SP, Spirulina platensis. Results shown are means \pm SD $(\mathrm{n}=8)$. Data were statistically considered at $\mathrm{p}<0.05$, and different small letters represent statistical differences.

공간 학습 능력 및 장기 기억력을 확인을 위한 Morris water maze 시험 결과는 Fig. 3 과 같다. 도피대 위치학습을 위한 hidden 시험(Fig. 3A) 기간 동안 모든 실험군에서 도피 대를 찾아가는 시간이 감소되었다. Hidden 시험 마지막 날 (day 4)의 결과는 $\mathrm{HFD}(21.89 \mathrm{sec})$ 는 $\mathrm{NC}(8.61 \mathrm{sec})$ 대비 도피 대를 찾아가는 시간이 감소됨을 확인 하였고, $\mathrm{CND}(11.98$ $\mathrm{sec})$ 및 $\mathrm{SP}(14.01 \mathrm{sec})$ 는 $\mathrm{NC}$ 와 통계적으로 유의적인 결과를 나타냄을 확인하였다. Hidden 시험 후, 도피대에 대한 기억 력을 확인하기 위하여 실시한 probe 시험의 결과는 Fig. 

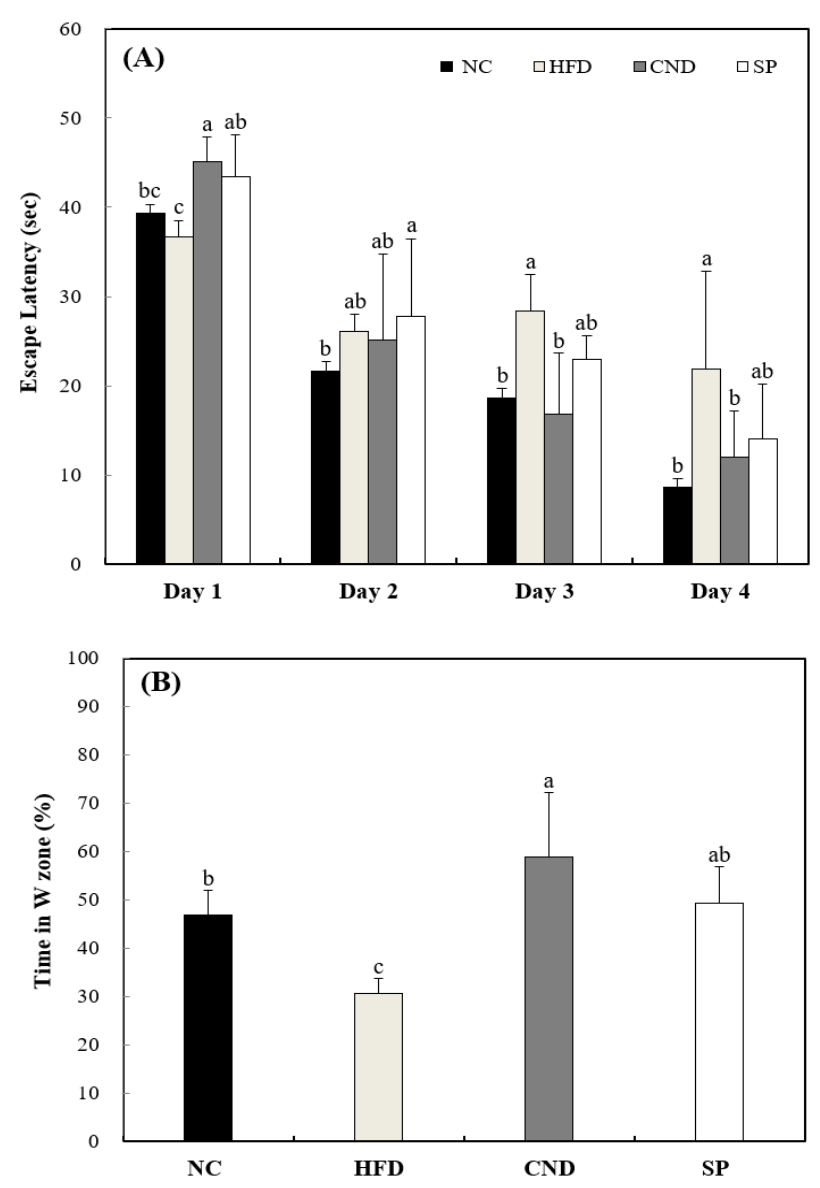

(C)
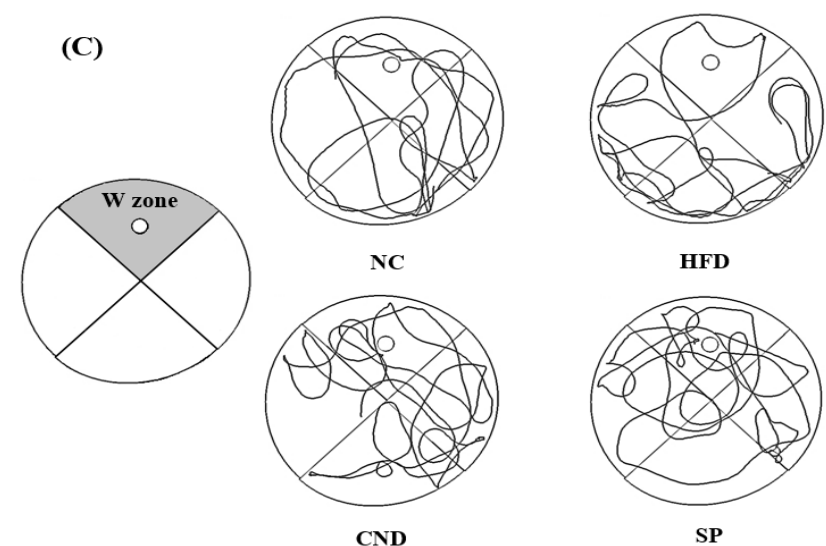

SP

Fig. 3. Effect of Spirulina platensis in high-fat diet-induced long-term learning and memory impairment.

Escape latency in the hidden test (A), time in $\mathrm{W}$ zone in the probe test (B) and path tracing of each groups in the probe test (C) on Morris water maze test. $\mathrm{NC}$, normal control; HFD, high-fat diet; CND, conversion of HFD to normal diet; $\mathrm{SP}$, Spirulina platensis. Results shown are means $\pm \mathrm{SD}(\mathrm{n}=8)$. Data were statistically considered at $\mathrm{p}<0.05$, and different small letters represent statistical differences.

$3 \mathrm{~B}$ 및 $3 \mathrm{C}$ 와 같다. 도피대가 존재한 $\mathrm{W}$ zone에 머무르는 시간을 계산한 결과(Fig. $3 \mathrm{~B}), \mathrm{NC}(46.82 \%)$ 대비 $\mathrm{HFD}$ 는 $30.68 \%$ 로 감소된 공간 학습 및 장기기억력에 대한 결과를 나타냈고, $\mathrm{CND}$ 는 $58.78 \%$ 로 상당히 개선된 결과 값을 나타

냈다. $\mathrm{SP}$ 는 $49.28 \%$ 로 일반식이 $\mathrm{CND}$ 대비 다소 낮은 기억력 을 나타내었지만, $\mathrm{HFD}$ 대비 약 $18.60 \%$ 높은 결과 값을 나타내어 고지방 식이로 유도된 학습 및 기억력 장애 개선 에 도움을 줄 수 있는 것으로 판단된다. Probe 시험에서 동물모델의 움직임에 대한 모식도(Fig. 3C)는 $\mathrm{HFD}$ 에서 도 피대가 존재하였던 $\mathrm{W}$ zone에서의 움직임이 $\mathrm{NC}$ 대비 감소 한 반면, $\mathrm{CND}$ 와 $\mathrm{SP}$ 에서는 다소 증가한 경향을 나타냄을 확인 할 수 있었다.

Amyloid- $\beta 1-42$ 를 주사하여 인지장애를 유발시킨 동물모 델에서 스피룰리나(Spirulina maxima) $70 \%$ 에탄올 추출물 이 Y-maze, passive avoidance, Morris water maze와 같은 공간인지 및 기억능력 시험에서 개선효과를 나타냈으며, 이러한 결과는 해마의 PI3K/Akt signaling pathway를 활성

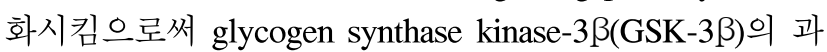
인산화 억제에 의한 것으로 보고하였다(30). 고지방 식이로 유도된 내당능 장애 역시 뇌 조직에서 PI3K/Akt signaling pathway를 활성화시킴으로써 인지장애를 유발하며, 스피 룰리나 섭취에 의하여 개선효과에 도움을 줄 수 있을 것으 로 판단된다. 또한, 신경영양인자 중 하나로 신경세포의 생존에 영향을 미치는 brain derived neurotophic factor $(\mathrm{BDNF})$ 는 고지방 식이에 의하여 감소되어 학습 및 기억력 장애를 유발시키는 것으로 보고되었으며(31), trimethyltin 처리로 신경독성을 유발한 HT-22 세포에서 스피룰리나 $70 \%$ 에탄올 추출물이 BDNF/cyclic AMP-responsive elementbinding protein signalling pathway 활성화를 유도함으로써 해마 유래 세포보호효과에 도움을 주는 것으로 보고하였다 (32). 따라서 이러한 연구들을 종합하여 볼 때, 고지방 식이 로 유발된 인지장애에 대하여 스피룰리나 섭취가 다양한 pathway에 관여함으로써 학습 및 기억력 개선효과에 도움 을 줄 수 있으며, GSK-3ß에 의한 $\mathrm{tau}$ 의 과인산화 및 amyloid- $\beta$ 와 같은 독성 물질 생성을 억제함으로써 알츠하 이머병과 같은 퇴행성 뇌신경질환을 예방하는데 도움이 될 것으로 판단된다.

\section{혈청 내 바이오마커 분석}

고지방으로 유도된 인지장애 동물모델에서 스피룰리나 섭취로 인한 혈중 성분 변화를 알아보기 위하여 혈청 내 바이오마커 함량을 측정한 결과는 Table 2-3과 같다. 간기능 지표인 GOT, GPT는 $\mathrm{HFD}$ 에서 함량이 증가하였고, $\mathrm{CND}$ 에 서는 모두 유의적으로 개선되었다(Table 2). 반면, SP(GOT; $56.80 \mathrm{U} / \mathrm{L}, \mathrm{GPT} ; 86.60 \mathrm{U} / \mathrm{L})$ 에서 GOT는 HFD(GOT; 86.80 $\mathrm{U} / \mathrm{L}, \mathrm{GPT} ; 58.20 \mathrm{U} / \mathrm{L})$ 대비 유의적인 감소를 나타냈지만, $\mathrm{GPT}$ 의 경우 오히려 증가된 함량을 나타냈다.

간 조직 손상 지표로 사용되는 GOT와 GPT는 간에 가장 많이 존재하는 효소로 알려져 있지만 GOT는 심장, 근육, 뇌 조직과 같은 다른 조직과의 상관관계도 높게 나타나며, GPT는 간 조직과의 상관관계가 높은 것으로 나타난다. 이 
Table 2. Analysis of serum biomarkers in mice with high fat diet

\begin{tabular}{ccccc}
\hline Group & NC $^{1)}$ & HFD & CND & SP \\
\hline GOT (U/L) & $45.00 \pm 1.41^{2)(3)}$ & $86.80 \pm 20.44^{\mathrm{a}}$ & $52.40 \pm 7.40^{\mathrm{bc}}$ & $56.80 \pm 9.52^{\mathrm{bc}}$ \\
GPT (U/L) & $28.00 \pm 2.45^{\mathrm{c}}$ & $58.20 \pm 19.84^{\mathrm{b}}$ & $35.40 \pm 2.61^{\mathrm{c}}$ & $86.60 \pm 36.60^{\mathrm{a}}$ \\
BUN (mg/dL) & $18.98 \pm 1.50^{\mathrm{a}}$ & $19.48 \pm 1.36^{\mathrm{a}}$ & $17.24 \pm 1.07^{\mathrm{ab}}$ & $17.82 \pm 1.77^{\mathrm{a}}$ \\
CRE (mg/dL) & $0.1 \pm 0^{\mathrm{a}}$ & $0.1 \pm 0^{\mathrm{a}}$ & $0.1 \pm 0^{\mathrm{a}}$ & $0.1 \pm 0^{\mathrm{a}}$ \\
LDH (U/L) & $134.00 \pm 16.70^{\mathrm{b}}$ & $279.40 \pm 90.89^{\mathrm{a}}$ & $246.80 \pm 68.30^{\mathrm{a}}$ & $217.40 \pm 39.85^{\mathrm{a}}$ \\
\hline
\end{tabular}

${ }^{1)} \mathrm{NC}$, normal control; HFD, high-fat diet; CND, conversion of HFD to normal diet; SP, Spirulina platensis.

${ }^{2}$ Results shown are means $\pm \mathrm{SD}(\mathrm{n}=8)$.

${ }^{3)}$ Data were statistically considered at $\mathrm{p}<0.05$, and different small letters represent statistical differences.

Table 3. Analysis of lipid metabolism-related biomarkers in blood serum

\begin{tabular}{ccccc}
\hline Group & $\mathrm{NC}^{1)}$ & HFD & CND & SP \\
\hline TG (mg/dL) & $\left.88.60 \pm 21.23^{4) \mathrm{ab} 5}\right)$ & $117.00 \pm 18.60^{\mathrm{a}}$ & $83.40 \pm 24.90^{\mathrm{b}}$ & $105.60 \pm 21.92^{\mathrm{ab}}$ \\
TCHO (mg/dL) & $99.40 \pm 18.77^{\mathrm{c}}$ & $146.40 \pm 21.77^{\mathrm{ab}}$ & $116.00 \pm 16.42^{\mathrm{bc}}$ & $180.00 \pm 37.08^{\mathrm{a}}$ \\
LDLC (mg/dL) & $20.28 \pm 5.33^{\mathrm{b}}$ & $36.40 \pm 5.97^{\mathrm{a}}$ & $17.52 \pm 2.18^{\mathrm{b}}$ & $24.08 \pm 19.21^{\mathrm{b}}$ \\
HTR (\%) & $61.86 \pm 1.01^{\mathrm{b}}$ & $63.15 \pm 4.26^{\mathrm{b}}$ & $70.33 \pm 3.76^{\mathrm{a}}$ & $74.90 \pm 9.05^{\mathrm{a}}$ \\
\hline
\end{tabular}

${ }^{1)} \mathrm{NC}$, normal control; HFD, high-fat diet; CND, conversion of HFD to normal diet; SP, Spirulina platensis.

${ }^{2)} \mathrm{LDLC}(\mathrm{mg} / \mathrm{dL})=\mathrm{TCHO}-(\mathrm{HDLC}+\mathrm{TG} / 5)$.

${ }^{3} \mathrm{HTR}(\%)=(\mathrm{HDLC}) / \mathrm{TCHO} \times 100$.

${ }^{4}$ Results shown are means $\pm \mathrm{SD}(\mathrm{n}=8)$.

${ }^{5}$ Data were statistically considered at $p<0.05$, and different small letters represent statistical differences.

러한 GOT와 GPT 차이는 다양한 life pattern과 같은 인자들 에게 영향을 받은 결과로 차이를 나타내며, logistic regression 분석에 따르면 GOT 관련 질환은 알코올 섭취, 고중성지질혈증(hypertriglyceridemia) 및 당뇨와의 관련성 을, GPT 관련 질환은 비만, 운동 부족, 고콜레스테롤혈증 (hypercholesterolemia), 및 고중성지질혈증 등의 원인으로 차이를 나타내는 것으로 알려져 있다(33). 또한 GOT는 80\% 이상이 미토콘드리아에 존재하지만, GPT는 오직 세포질에 만 존재하여 비만에 의한 지방간과 같은 간 손상이 일어날 시 세포질 효소의 누출이 증가되어 GPT 증가가 주로 일어 난다고 보고된다(34). 따라서 스피룰리나의 섭취에 따른 GPT 함량 변화는 정상식이로의 전환군 대비 지속적인 고지 방식이에 따른 영양학적 스트레스에 의한 것으로 사료되 나, 보다 명확한 원인과 그 기작은 향후 연구를 통해 구체적 으로 밝혀야 할 것이다.

신장 기능 지표인 CRE, BUN에서는 거의 모든 그룹에서 통계적으로 유의적인 차이를 나타내지 않았다. $\mathrm{LDH}$ 함량 측정결과는 $\mathrm{NC}(134.00 \mathrm{mg} / \mathrm{dL})$ 대비 $\mathrm{HFD}(279.40 \mathrm{mg} / \mathrm{dL})$ 에 서 약 2.06 배 증가된 함량을 나타냈다. $\operatorname{SP}(217.40 \mathrm{mg} / \mathrm{dL})$ 는 $\mathrm{CND}(246.80 \mathrm{mg} / \mathrm{dL})$ 보다 감소된 결과 값을 나타내었지만 통계적으로 유의적인 결과를 나타내지 못하였다.

혈청 내 지질관련 바이오마커 함량을 측정 결과(Table 3), $\mathrm{TG}$ 측정 결과는 $\mathrm{HFD}(117.00 \mathrm{mg} / \mathrm{dL})$ 는 $\mathrm{NC}(88.60 \mathrm{mg} / \mathrm{dL})$ 대비 증가된 함량을 나타냈으며, $\mathrm{CND}(83.40 \mathrm{mg} / \mathrm{dL})$ 와
$\mathrm{SP}(105.60 \mathrm{mg} / \mathrm{dL})$ 에서 $\mathrm{NC}$ 수준으로 유의적 감소 경향을 확인하였다. $\mathrm{TCHO}$ 함량 측정 결과는 $\mathrm{SP}(180.00 \mathrm{mg} / \mathrm{dL})$ 에 서 $\mathrm{HFD}(146.40 \mathrm{mg} / \mathrm{dL})$ 대비 오히려 증가된 경향을 나타내 었는데, 이러한 결과는 GPT와 유사한 경향을 나타내고 있 다. 이 역시 정상식이로의 전환군 대비 지속적인 고지방식 이에 따른 영양학적 스트레스에 의한 $\mathrm{TCHO}$ 의 상대적 증가 로 사료되나, 보다 명확한 원인과 그 기작은 향후 연구를 통해 더불어 규명할 필요가 있을 것이다. LDLC 함량 측정 한 결과, $\mathrm{HFD}(36.40 \mathrm{mg} / \mathrm{dL})$ 에서 $\mathrm{NC}(20.28 \mathrm{mg} / \mathrm{dL})$ 대비 약 1.79 배 증가된 것을 보였으며, $\mathrm{SP}(24.08 \mathrm{mg} / \mathrm{dL})$ 는 $\mathrm{NC}$ 과 같이 유의적으로 감소되는 결과를 나타냈다. 또한, TCHO 중 $\mathrm{HDLC}$ 의 비율을 나타내는 $\mathrm{HTR}$ 계산 결과에서도 $\mathrm{HFD}(63.15 \%)$ 대비 $\mathrm{SP}(74.90 \%)$ 에서 $\mathrm{HDLC}$ 함량이 유의적 으로 증가했음을 확인할 수 있었다. 이러한 결과들을 고려 할 때, 스피룰리나 섭취로 인해 유도되는 유의적으로 높은 $\mathrm{HTR}(\mathrm{HDLC}$ 의 비율) 값에 의하여 혈중 콜레스테롤 개선에 도움을 줄 것으로 사료된다.

$\mathrm{HDLC}$ 는 말초 조직과 혈관 벽에 축적되어 있는 콜레스테 롤을 분산시켜 혈중 콜레스테롤의 양을 저하시키기 때문에 심혈관 질환 및 그와 관련된 다양한 질환에 대한 방어 작용 에 도움을 줄 수 있다. 반면, LDLC는 간에 존재하는 콜레스 테롤을 모세혈관을 통해 다른 조직으로 운반하며, $\mathrm{LDLC}$ 의 함량이 높을 시 혈관에 콜레스테롤이 쌓일 위험이 높아 심혈관 질환의 위험요인으로 작용한다(35). 뿐만 아니라, 
대사성 내당능 장애가 발생되면 미토콘드리아 기능저하에 따른 ROS 생성과 같은 산화적 스트레스가 발생되고, LDLC을 산화(oxidized LDL; oxo-LDL)시키게 된다. Lipid hydroperoxide, aldehydes, 콜레스테롤산화생성물(7-ketocholesterol[7KC], 25-hydroxycholesterol[25HC])과 같은 oxo-LDLC는 혈관 내 plague 생성을 가속화 시킬 뿐만 아니라, 신경세포 내 LDL 수용체를 자극함으로써 신경세포의 손상과 사멸을 유발시 키는 것으로 알려져 있다(36). Kata 등(16)의 연구에서 고콜 레스테롤 식이로 콜레스테롤혈증이 유도된 토끼에 스피룰 리나 알칼리 추출물을 섭취시킬 시 $\mathrm{LDL}$ 가 감소되고 $\mathrm{HDL}$ 이 증가되어 혈중 콜레스테롤 개선에 효능을 보였으며, 주 요 물질은 omega-6 계열의 linoleic acid, gamolenic $\operatorname{acid}(\mathrm{GLA})$ 가 갖는 지질 산화 방지 활성에서 기인된 것이라 보고하였다. 이러한 결과들을 참고해 볼 때, 스피룰리나의 섭취는 혈중 콜레스테롤 개선효과를 바탕으로 고지방 식이 로 인하여 유발되는 다양한 질병에 대한 예방 및 개선에 도움을 줄 수 있는 소재라고 판단된다.

\section{뇌, 간 조직의 항산화 효능 평가}

비만과 같은 다양한 원인으로 인해 고혈당 상태가 지속 되면 ROS 생성을 촉진시키며(8), 이러한 산화적 스트레스 에 취약한 뇌 조직은 생성된 ROS에 의하여 뇌신경세포의 기능장애 및 사멸이 유도되어 퇴행성 뇌신경질환이 유발될 수 있다(9). 따라서 고지방 식이로 유도된 인지장애를 유발 시킨 동물모델의 간과 뇌 조직에서 $\mathrm{ROS}$ 를 1 차적으로 제거 해 주는 내인성 항산화인자인 SOD의 함량 변화를 통해 스피룰리나의 항산화 효과를 측정하였고, 그 결과는 Fig. 4 와 같다. 뇌 조직에서 $\mathrm{SOD}$ 함량을 측정한 결과는 $\mathrm{NC}(16.08 \mathrm{U} / \mathrm{mg}$ of protein) 대비 HFD(9.65 U/mg of protein) 가 약 $17.72 \%$ 감소된 결과를 나타냈다(Fig. $4 \mathrm{~A}) . \mathrm{SP}(17.42$ $\mathrm{U} / \mathrm{mg}$ of protein)는 $\mathrm{CND}(15.81 \mathrm{U} / \mathrm{mg}$ of protein)와 유의적으 로 높은 $\mathrm{SOD}$ 함량을 나타내었다. 간 조직의 $\mathrm{SOD}$ 함량은 $\mathrm{HFD}(15.07 \mathrm{U} / \mathrm{mg}$ of protein)가 $\mathrm{NC}(22.22 \mathrm{U} / \mathrm{mg}$ of protein) 대비 약 $32.18 \%$ 감소된 함량을 나타냈으며, $\mathrm{SP}(20.76 \mathrm{U} / \mathrm{mg}$ of protein)는 $\mathrm{CND}(22.86 \mathrm{U} / \mathrm{mg}$ of protein $)$ 보다는 다소 낮은 수준의 SOD 함량을 회복시키는 것으로 나타났지만, HFD 대비 약 $37.76 \%$ 증가된 함량을 나타냈다(Fig. 4B).

$\mathrm{GSH}$ 는 세포 내 항산화 시스템을 조절하는 중요한 비단 백질성 thiol group으로, 산화 반응에 의하여 hydrogen과 peroxides를 환원하여 radical을 소거하며 oxidized GSH로 변환된다. 따라서 조직 내 total GSH 함량에 대한 oxidized $\mathrm{GSH}$ 의 비율을 분석한 결과 뇌 조직에서의 oxidized GSH 함량이 $\mathrm{NC}(10.88 \%)$ 에 비하여 $\mathrm{HFD}$ 의 경우 $16.42 \%$ 를 나타 내어 oxidized $\mathrm{GSH}$ 의 비율이 증가된 것으로 나타났으며, $\mathrm{CND}$ 와 $\mathrm{SP}$ 는 각각 $12.55,12.75 \%$ 로 oxidized $\mathrm{GSH}$ 를 효과적 으로 억제한 것으로 나타났다(Fig. 4C). 간 조직에서는 $20.41 \%$ 인 $\mathrm{NC}$ 에 비하여 고지방 식이를 섭취함으로써
$28.10 \%$ 로 oxidized $\mathrm{GSH}$ 의 비율이 증가된 것을 보였으며, $\mathrm{CND}$ 와 $\mathrm{SP}$ 는 각각 $24.82,22.58 \%$ 로 oxidized $\mathrm{GSH}$ 를 억제하 는 것을 나타냈다(Fig. 4D).

뇌에는 불포화 지방산이 많이 함유되어 있어 산화적 스 트레스에 취약하며, ROS에 의하여 산화 반응의 결과로 malondialdehyde(MDA)와 같은 지질 과산화물을 생성한다. 따라서 고지방 식이로 유발된 인지장애 모델에서 적출된 조직을 이용하여 스피룰리나 섭취가 $\mathrm{MDA}$ 함량 변화에 영향을 미치는지 확인하였다. $\mathrm{HFD}$ 의 $\mathrm{MDA}$ 함량은 뇌 조직 에서 $4.62 \mathrm{nmole} / \mathrm{mg}$ protein인 $\mathrm{NC}$ 에 비하여 $5.73 \mathrm{nmole} / \mathrm{mg}$ protein으로 약 $24.03 \%$ 증가를 나타냈다. 반면, $\mathrm{CND}$ 와 $\mathrm{SP}$ 은 $\mathrm{MDA}$ 함량이 각각 $4.62,4.79 \mathrm{nmole} / \mathrm{mg}$ protein으로 유의적 인 지질과산화 억제효과를 나타냈다(Fig. $4 \mathrm{E})$. 또한, 간 조직 에서는 $\mathrm{HFD}(5.69 \mathrm{nmole} / \mathrm{mg}$ protein $)$ 은 $\mathrm{NC}(3.05 \mathrm{nmole} / \mathrm{mg}$ protein)대비 $\mathrm{MDA}$ 의 함량 증가를 나타내었으며, $\mathrm{CND}$ 와 $\mathrm{SP}$ 은 각각 $2.98,3.45 \mathrm{nmole} / \mathrm{mg}$ protein의 수준으로 지질과 산화 효과를 나타냈다(Fig. 4F).

Ray와 Roy(37)에 따르면 cisplatin으로 유도된 지질 과산 화물에서 스피룰리나가 갖는 항산화 활성을 측정한 결과 스피룰리나의 물 추출물이 유리 라디칼을 소거하여 $\mathrm{GSH}$ 산화 및 $\mathrm{MDA}$ 생성을 억제하는 효과가 있음을 보고하였다. 또한, Meineri 등(38)의 연구에서는 고지방 식이를 통해 비 만이 유도된 토끼에서 스피룰리나 섭취에 의하여 혈중 지질 대사물 및 ROS 함량이 감소되는 것을 확인했으며, 그 효과 는 스피룰리나에 포함된 linolenic acid의 효능으로 보인다 고 보고하였다. 이러한 결과들을 고려하여 스피룰리나의 항산화 효과를 평가하여 볼 때, 뇌와 간 조직에서 뛰어난 항산화 효과는 고지방 식이로 유발되는 다양한 산화적 스트 레스에 대한 보호 효과를 통하여, 뇌 기능 장애에 대한 예방 및 개선에 도움을 줄 수 있을 것이라고 판단된다. 또한, 간 조직에서는 혈청분석에서 나타난 GPT 함량 증가(Table 2)의 결과와 대조적으로 스피룰리나 섭취가 고지방 식이로 유도된 간 손상에서 항산화 시스템을 활성화시킴으로써 간 조직을 보호하는데 도움이 될 것으로 판단된다.

\section{마우스 뇌 조직 중의 acetylcholinesterase(AChE) 활성 측정}

신경전달물질인 acetylcholine(ACh)은 choline과 acetyl coenzyme A(acetyl-CoA)가 합성되어 생성되며, 내당능 장 애 등으로 인하여 포도당 이용에 문제가 생길 시 acetyl-CoA 형성을 감소시켜 $\mathrm{ACh}$ 생성이 감소된다(39). 인지장애는 $\mathrm{ACh}$ 의 생성량이 감소되는 반면, 이를 분해하는 효소인 acetylcholinesteras $(\mathrm{AChE})$ 활성이 일정 수준으로 진행되어 시냅스 사이의 신경전달이 제대로 이루어지지 못해 콜린성 시스템에 장애를 일으켜 발생된다(40). 따라서 고혈당성 장애로 인해 손상된 콜린성 시스템에 대한 개선효과를 $\mathrm{AChE}$ 의 활성을 측정함으로써 확인하였다(Fig. 5). HFD는 

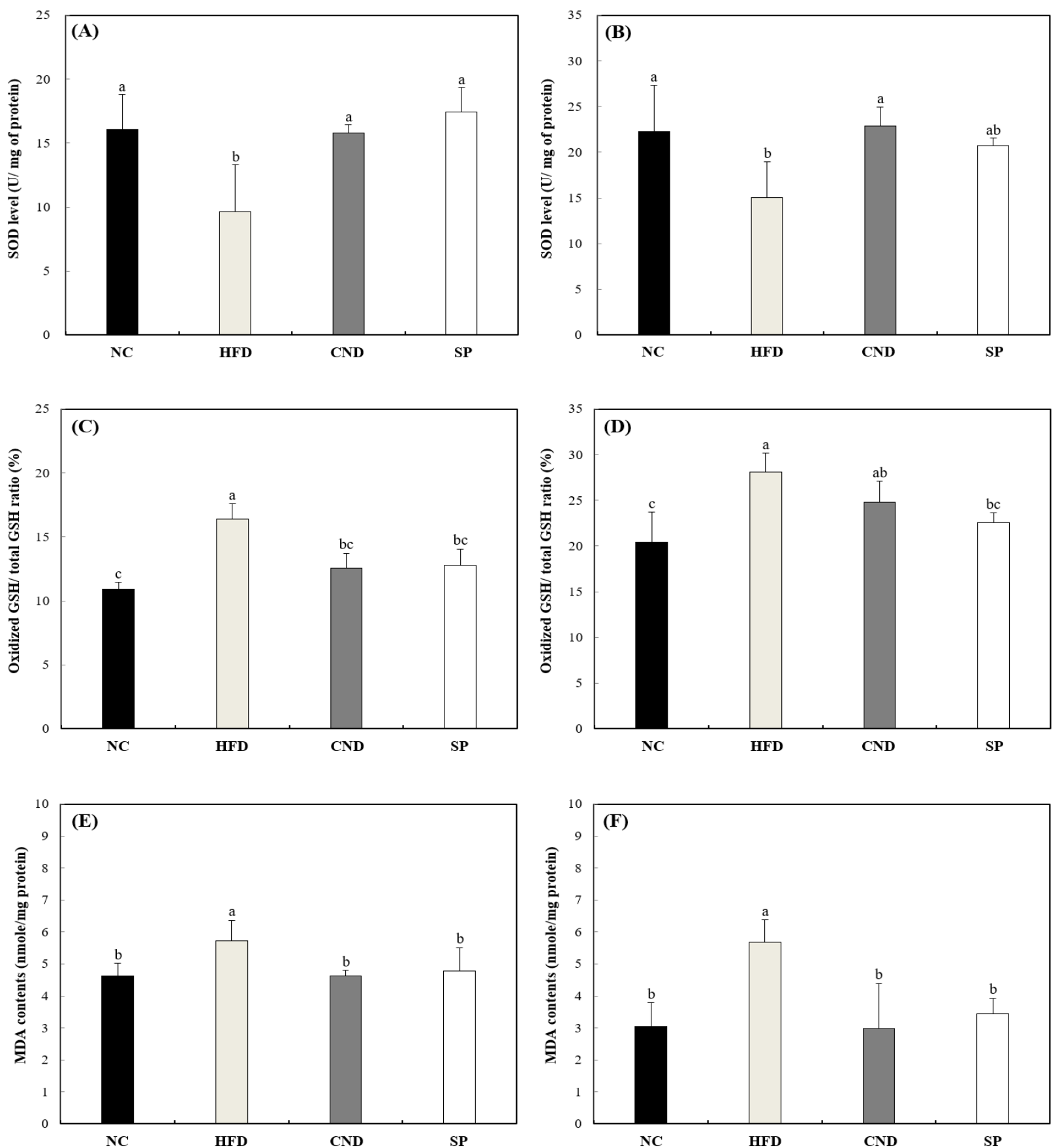

Fig. 4. Antioxidant effect of Spirulina platensis on high-fat diet-induced cognitive dysfunction mice.

Superoxide dismutase (SOD) contents in brain tissue (A) and liver tissue (B), oxidized GSH/total GSH contens in mice brain tissue (C) and liver tissue (D), and malondialdehyde $(\mathrm{MDA})$ contents in mice brain tissue (E) and liver tissue (F).

NC, normal control; HFD, high-fat diet; CND, conversion of HFD to normal diet; SP, Spirulina platensis. Results shown are means \pm SD ( $\mathrm{n}=8$ ). Data were statistically considered at $\mathrm{p}<0.05$, and different small letters represent statistical differences.

$\mathrm{NC}(100.00 \%)$ 대비 $181.50 \%$ 로 $\mathrm{AChE}$ 활성을 증가시켰으며, 이러한 결과는 고지방식이로 유도된 내당능 장애 등에 의하 여 콜린성 시스템의 장애를 유발시킨 것으로 판단된다. $\mathrm{SP}(142.34 \%)$ 는 $\mathrm{CND}(151.71 \%)$ 대비 다소 높은 저해효과를 나타내었으며, 효과적으로 콜린성 시스템 장애에 대한 개
선시킴으로써 뇌기능 손상에 회복에 도움을 줄 수 있을 것으로 판단된다.

Olasehinde 등(41)은 미세조류들의 $\mathrm{AChE}$ 활성 저해 효과 는 lutein 및 zeaxanthin 이성질체에 의하여 결정되며, DHA 와 같은 polyunsaturated fatty acids(PUFAs)를 보충해주어 


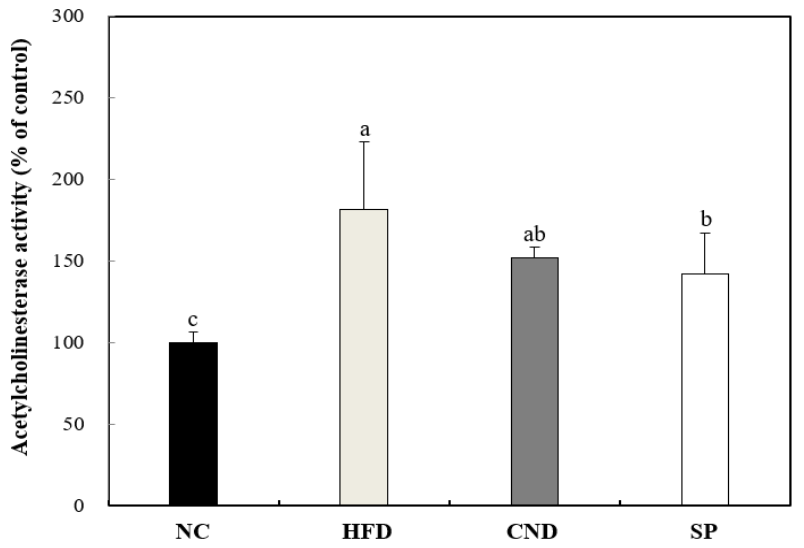

Fig. 5. Inhibitory effect of Spirulina platensis against acetylcholinesterase (AChE) activity on high-fat diet-induced cholinergic system dysfunction.

$\mathrm{NC}$, normal control; HFD, high-fat diet; CND, conversion of HFD to normal diet; SP, Spirulina platensis. Results shown are means $\pm \mathrm{SD}(\mathrm{n}=8)$. Data were statistically considered at $\mathrm{p}<0.05$, and different small letters represent statistical differences.

해마에서의 $\mathrm{ACh}$ 방출을 증가시켜준다고 보고하였다. 또, 뇌신경세포의 $\mathrm{AChE}$ 활성이 억제되면 PI3K/Akt signaling pathway 활성화에 의하여 tau 단백질의 과인산화를 일으키 는 GSK-3 $\beta$ 활성이 억제되어 뇌신경세포의 생존율을 높일 수 있다고 보고하였다(39). 이러한 연구들을 고려해 볼 때, 스피룰리나의 $\mathrm{AChE}$ 저해효과는 고혈당성 장애 등으로 인 해 손상된 콜린성 시스템을 일부 회복시킴으로써 뇌기능 개선 효과에 도움을 줄 수 있는 것으로 사료된다. 결국 고지 방 식이로 유도되는 인지장애 개선에 있어 식이요법도 매우 중요하지만, 스피룰리나와 같은 항산화 효과 및 콜린성 시 스템 개선 효과를 갖는 소재에 대한 섭취 또한 매우 중요하 다고 판단된다.

\section{요 약}

본 연구는 고지방 식이로 유발된 내당능 장애 모델의 학습 및 기억력 장애에 대한 스피룰리나 섭취의 개선 효과 를 확인하고자 하였다. 당부하 검사(IPGTT)를 통하여 고지 방식이를 통한 내당능 장애가 유발되었음을 확인하였고, $\mathrm{SP}$ 는 $\mathrm{HFD}$ 대비 약 $20 \%$ 의 당 내성 개선효과를 나타내는 것으로 나타났다. 고지방 식이로 인지 기능 손상을 유발시 킨 동물모델의 Y-maze 및 Morris water maze 시험을 진행한 결과는 $\mathrm{SP}$ 에서 $\mathrm{CND}$ 대비 학습 및 장.단기기억력 장애가 유의한 수준으로 개선됨을 확인하였다. 실험동물의 혈청분 석 결과는 스피룰리나 섭취가 일반식이로 전환한 것과 비교 하였을 때, HFD 대비 LDLC 감소 및 HTR(HDLC의 비율) 증가를 통한 혈중 콜레스테롤 개선에 효과를 나타냈다. 적 출된 뇌와 간 조직을 대상으로 $\mathrm{SOD}$ 활성, oxidized GSH
함량 및 $\mathrm{MDA}$ 함량을 측정한 결과 스피룰리나 섭취가 뇌 조직뿐만 아니라 간 조직에서 항산화 활성을 향상시켜 주는 것도 역시 확인할 수 있었다. 이러한 결과는 고지방 식이를 통한 혈당 상승 및 이로 인한 기억능력 저하에서 스피룰리 나 섭취는 $\mathrm{CND}$ 수준으로의 개선 효과를 유도할 수 있음을 확인하였다. 또한, 스피룰리나 섭취는 뇌 기능과 직접적으 로 연관된 콜린성 시스템 손상에도 $\mathrm{CND}$ 대비 $\mathrm{AChE}$ 활성에 더 높은 저해효과를 나타냄을 확인하였다. 따라서 본 연구 는 스피룰리나가 고지방 식이로 유도된 내당능 장애 모델에 서 발생될 수 있는 뇌기능 저하에서 혈중 콜레스테롤 개선 효과, 항산화 효과 및 $\mathrm{AChE}$ 저해효과를 통하여, 비만으로 유도될 수 있는 대사성 인지 장애에 대한 개선 소재로의 잠재적인 가능성을 갖는 것으로 판단된다.

\section{감사의 글}

본 연구는 해양수산부의 “해양수산생명 공학기술개발사 업(20170297)" 및 2015년도 과학기술정보통신부의 재원으 로 한국연구재단(No. 2015R1C1A1A01054303)의 지원을 받아 수행된 연구결과이며, 이에 감사드립니다.

\section{References}

1. Yamauchi T, Kamon J, Waki H, Terauchi Y, Kubota N, Hara K, Mori Y, Ide T, Murakami K, TsuboyamaKasaoka N, Ezaki O, Akanuma Y, Gavrilova O, Vinson C, Reitman ML, Kagechika H, Shudo K, Yoda M, Nakano $Y$, Tobe K, Nagai R, Kimura S, Tomita M, Froguel P, Kadowaki T (2001) The fat-derived hormone adiponectin reverses insulin resistance associated with both lipoatrophy and obesity. Nat Med, 7, 941-946

2. Mathieu P, Poirier P, Pibarot P, Lemieux I, Despres JP (2009) Visceral obesity: the link among inflammation, hypertension, and cardiovascular disease. Hypertension, 53, 577-584

3. Greenfield JR, Campbell LV (2004) Insulin resistance and obesity. Clin Dermatol, 22, 289-295

4. Amati F, Dube JJ, Alvarez-Carnero E, Edreira MM, Chomentowski P, Coen PM, Switzer GE, Bickel PE, Stefanovic-Racic M, Toledo FG, Goodpaster BH (2011) Skeletal muscle triglycerides, diacylglycerols, and ceramides in insulin resistance: another paradox in endurance-trained athletes?. Diabetes, 60, 2588-2597

5. Hoyer S (2004) Glucose metabolism and insulin receptor signal transduction in Alzheimer disease. Eur $\mathbf{J}$ 
Pharmacol, 490, 115-125

6. Stranahan AM, Norman ED, Lee K, Cutler RG, Telljohann RS, Egan JM, Mattson MP (2008) Diet-induced insulin resistance impairs hippocampal synaptic plasticity and cognition in middle-aged rats. Hippocampus, 18, 1085-1088

7. Park HR, Park M, Choi J, Park KY, Chung HY, Lee J (2010) A high-fat diet impairs neurogenesis: involvement of lipid peroxidation and brain-derived neurotrophic factor. Neurosci Lett, 482, 235-239

8. Brownlee M (2001) Biochemistry and molecular cell biology of diabetic complications. Nature, 414, 813-820

9. Zhang L, Zhao B, Yew DT, Kusiak JW, Roth GS (1997) Processing of Alzheimer's amyloid precursor protein during $\mathrm{H}_{2} \mathrm{O}_{2}$-induced apoptosis in human neuronal cells. Biochem Biophys Res Commun, 235, 845-848

10. Gonzalez-Periz A, Horrillo R, Ferre N, Gronert K, Dong B, Moran-Salvador E, Claria J (2009) Obesity-induced insulin resistance and hepatic steatosis are alleviated by a-3 fatty acids: a role for resolvins and protectins. FASEB J, 23, 1946-1957

11. Pintana H, Apaijai N, Pratchayasakul W, Chattipakorn N, Chattipakorn SC (2012) Effects of metformin on learning and memory behaviors and brain mitochondrial functions in high fat diet induced insulin resistant rats. Life Sci, 91, 409-414

12. Maritim AC, Sanders RA, Watkins JB (2003) Diabetes, oxidative stress, and antioxidants: a review. J Biochem Mol Toxicol, 17, 24-38

13. Tokusoglu O, Uunal MK (2003) Biomass nutrient profiles of three microalgae: Spirulina platensis, Chlorella vulgaris, and Isochrisis galbana. J Food Sci, 68, 1144-1148

14. Romano I, Bellitti MR, Nicolaus B, Lama L, Manca MC, Pagnotta E, Gambacorta A (2000) Lipid profile: a useful chemotaxonomic marker for classification of a new cyanobacterium in Spirulina genus. Phytochemistry, 54, 289-294

15. Kuhad A, Tirkey N, Pilkhwal S, Chopra K (2006) Effect of Spirulina, a blue green algae, on gentamicin-induced oxidative stress and renal dysfunction in rats. Fundam Clin Pharmacol, 20, 121-128

16. Kata FS, Athbi AM, Manwar EQ, Al-Ashoor A, Abdel-Daim MM, Aleya L (2018) Therapeutic effect of the alkaloid extract of the cyanobacterium Spirulina platensis on the lipid profile of hypercholesterolemic male rabbits. Environ Sci Pollut Res, 25, 19635-19642
17. Kim HS, Kim CH, Kwon MC, Song YK, Cho JH, Gwak HG, Hwang BY, Kim JC, Lee HY (2006) Anticancer activity of ultrasonified extracts from seawater-based culture of the microalga Spirulina platensis. Korean J Fish Aquat Sci, 39, 318-325

18. Hernandez-Corona A, Nieves I, Meckes M, Chamorro G, Barron BL (2002) Antiviral activity of Spirulina maxima against herpes simplex virus type 2. Antiviral Res, 56, 279-285

19. Son CW, Shin YM, Sim HJ, Kim MY, Kim MR (2007) Effect of spirulina on growth of lactic acid bacteria. Korean J Food Cookery Sci, 23, 968-976

20. Jung JY, Yang JW, Kim K, Hwang KT, Jung SM, Kwon JH (2015) Cost-efficient cultivation of Spirulina platensis by chemical absorption of $\mathrm{CO}_{2}$ into medium containing $\mathrm{NaOH}$. Korean J Chem Eng, 32, 2285-2289

21. Morris R (1984) Developments of a water-maze procedure for studying spatial learning in the rat. $\mathrm{J}$ Neurosci Methods, 11, 47-60

22. Friedewald WT, Levy RI, Fredrickson DS (1972) Estimation of the concentration of low-density lipoprotein cholesterol in plasma, without use of the preparative ultracentrifuge. Clin Chem, 18, 499-502

23. Ellman GL, Courtney KD, Andres V, Featherstone RM (1961) A new and rapid colorimetric determination of acetylcholinesterase activity. Biochem Pharmacol, 7, 88-90

24. Brands AM, Biessels GJ, Kappelle LJ, de Haan EH, de Valk HW, Algra A, Kessels RP (2007) Cognitive functioning and brain MRI in patients with type 1 and type 2 diabetes mellitus: a comparative study. Dementia Geriatr Cognit Disord, 23, 343-350

25. Hwang EY, Hong JH, Choi JH, Choi EJ, Lee IS (2009) Study on anti-obesity and hypoglycemic effects of Lycium chinense Mill extracts. J Korean Soc Food Sci Nutr, 38, 1528-1534

26. Kim BB, Hyun CK (2015) Suppression of fat accumulation and improvement of glucose tolerance in high-fat diet-induced obese mice treated with an Acanthopanax senticosus extract. Korean J Pharmacogn, 46, 65-71

27. Mallikarjun Gouda KG, Kavitha MD, Sarada R (2015) Antihyperglycemic, antioxidant and antimicrobial activities of the butanol extract from Spirulina platensis. J food Biochem, 39, 594-602

28. Ou Y, Lin L, Pan Q, Yang X, Cheng X (2012) Preventive effect of phycocyanin from Spirulina platensis on 
alloxan-injured mice. Environ Toxicol Pharmacol, 34, 721-726

29. Ma QY, Fang M, Zheng JH, Ren DF, Lu J (2016) Optimised extraction of $\beta$-carotene from Spirulina platensis and hypoglycaemic effect in streptozotocininduced diabetic mice. J Sci Food Agric, 96, 1783-1789

30. Koh EJ, Kim KJ, Song JH, Choi J, Lee HY, Kang DH, Heo HJ, Lee BY (2017) Spirulina maxima extract ameliorates learning and memory impairments via inhibiting GSK-3 $\beta$ phosphorylation induced by intracerebroventricular injection of amyloid- $\beta$ 1-42 in mice. Int J Mol Sci, 18, 2401

31. White CL, Pistell PJ, Purpera MN, Gupta S, Fernandez-Kim SO, Hise TL, Keller JN, Ingram DK, Morrison CD, Bruce-Keller AJ (2009) Effects of high fat diet on Morris maze performance, oxidative stress, and inflammation in rats: contributions of maternal diet. Neurobiol Dis, 35, 3-13

32. Koh EJ, Seo YJ, Choi J, Lee HY, Kang DH, Kim KJ, Lee BY (2017) Spirulina maxima extract prevents neurotoxicity via promoting activation of BDNF/CREB signaling pathways in neuronal cells and mice. Molecules, 22, 1363

33. Mukai M, Ozasa K, Hayashi K, Kawai K (2002) Various $\mathrm{S}-\mathrm{GOT} / \mathrm{S}-\mathrm{GPT}$ ratios in nonviral liver disorders and related physical conditions and life-style. Dig Dis Sci, 47, 549-555
34. Jang HO, Lee CG, Kang YJ (2002) The prevalent rates of abnormal serum aminotransferase levels and total cholesterol levels among adolescents with obesity. J Korean Pediatr Soc, 45, 1484-1490

35. Duntas LH (2002) Thyroid disease and lipids. Thyroid, 12, 287-293

36. Bacchetti T, Vignini A, Giulietti A, Nanetti L, Provinciali L, Luzzi S, Mazzanti L, Ferretti G (2015) Higher levels of oxidized low density lipoproteins in Alzheimer's disease patients: roles for platelet activating factor acetyl hydrolase and paraoxonase-1. J Alzheimer's Dis, 46, 179-186

37. Ray S, Roy K, Sengupta C (2007) Evaluation of protective effects of water extract of Spirulina platensis (blue green algae) on cisplatin-induced lipid peroxidation. Indian J Pharm Sci, 69, 378-383

38. Meineri G, Ingravalle F, Radice E, Aragno M, Peiretti PG (2009) Effects of high fat diets and Spirulina Platensis supplementation in New Zealand White rabbit. J Anim Vet Adv, 8, 2735-2744

39. Neumann KF, Rojo L, Navarrete LP, Farias G, Reyes P, Maccioni RB (2008) Insulin resistance and Alzheimer's disease: molecular links \& clinical implications. Curr Alzheimer Res, 5, 438-447

40. Lane RM, Potkin SG, Enz A (2006) Targeting acetylcholinesterase and butyrylcholinesterase in dementia. Int J Neuropsychopharmacol, 9, 101-124

41. Olasehinde TA, Olaniran AO, Okoh AI (2017) Therapeutic potentials of Microalgae in the treatment of Alzheimer's disease. Molecules, 22, 1-18 